\title{
A review of the taxonomy and seroepizootiology of Vibrio anguillarum, with special reference to aquaculture in the northwest of Spain
}

\author{
Alicia E. Toranzo, Juan L. Barja \\ Departamento de Microbiología y Parasitología, Facultad de Biología, Universidad de Santiago, \\ E-15706 Santiago de Compostela, Spain
}

\begin{abstract}
A review of the literature shows that although the number of serotypes of Vibrio anguillarum reported from different countries varies, most of the vibriosis outbreaks throughout the world are caused by only 2 serotypes: $\mathrm{O} 1$ and $\mathrm{O} 2$ (European serotype designation). The remaining serotypes, associated mainly with environmental samples such as water, sediment, phyto- and zooplankton, are generally non-pathogenic to fish. This raises the question as to whether the 2 major pathogenic serotypes of $V$. anguillarum (isolated only from diseased or carrier fish) should be considered opportunistic or obligate fish pathogens. In addition, information useful in epizootiological and vaccination studies is presented about the antigenic heterogeneity detected within serotype O2. In this review, emphasis is placed on the presence in the marine environment of vibrios (presumptively assigned to the $V$. splendidus and $V$. pelagius) species that are taxonomically and serologically related with $V$ anguillarum and some of which have been associated with disease in fish cultured on the Atlantic coast of Spain and Norway. The precise phylogenetic position of these $V$ anguillarum-like organisms are well as their actual threat to marine aquaculture remains to be clarified.
\end{abstract}

\section{INTRODUCTION}

Vibriosis is a serious disease problem in the fish culture industry in saline waters with a worldwide occurrence. In addition, it affects a great variety of species regardless of fish size, season, or source of seedlings.

Galicia (northwestern Spain) is a very important mariculture site. However vibriosis, caused by Vibrio anguillarum and $V$. tubiashii, is one of the most threatening bacterial infections limiting the production of marine fish and shellfish, respectively, in this area (Devesa et al. 1985, Bolinches et al. 1986, Lodeiros et al. 1987, Toranzo et al. 1987a).

The taxonomy and serology of the genus Vibrio have been the subject of continuous revision in recent years. Despite this, a large number of isolates are still referred to as Vibrio spp. In fact, there are vibrios in the estuarine environment taxonomically and serologically related to $V$. anguillarum and V. tubiashii (Bryant et al. 1986, Fouz et al. 1990), some of which are implicated in disease problems in marine fishes (Lupiani et al. 1989a). These vibrios are phylogenetically closely related and can be designated as $V$. anguillarum-like organisms (Larsen 1982, 1983, Bryant et al. 1986, Fouz et al. 1990).

Vibrio anguillarum and other related pathogenic vibrios have been considered common members of the estuarine and marine habitats and, hence, facultative fish pathogens. However, although 10 serotypes are known to occur in this species, only 2 of them (O1 and O2, European serotype designation) (Sørensen \& Larsen 1986) have been isolated from diseased fish, the remaining serotypes having been detected in environmental samples. Therefore, the precise role of the marine environment as a reservoir of vibriosis has not been clarified.

In this paper, we review the rapidly growing body information on the taxonomy, serology, and ecology of Vibrio anguillarum. Our hope is that the review will contribute to an international harmonization of the seroepizootiological information on the vibrios, thus facilitating the formulation of vaccines that contain the strains and serotypes representative of the needs of a given area. 


\section{TAXONOMY}

Although Vibrio anguillarum is the most studied aetiological agent of vibriosis, other members of the genus Vibrio have been implicated in epizootics of cultured and wild marine fish and shellfish. Table 1 lists the published reports on vibriosis outbreaks in fish, molluscs, and crustacea in which $V$. anguillarum has been phenotypically identified as the causative organism; also listed are the geographic areas involved and the species affected. Unfortunately, in some of these reports confirmation of the identification by serology was not provided.

Some of the Vibrio strains pathogenic to larvae of bivalve molluscs were compared with Vibrio species isolated from fish and the marine environment including $V$. anguillarum, $V$. ordalii, $V$. nereis, $V$. fluvialis, $V$. diazotrophicus, and $V$. splendidus (Hada et al. 1984). It was found that the strains from shellfish were distinct phenotypically and genotypically from the other Vibrio spp., being assigned to the new species $V$. tubiashii. $V$. tubiashii differed from $V$. anguillarum mainly in its ability to degrade xanthine and tyrosine, both traits being unusual for the Vibrio genus. These 2 biochemical properties were also detected in the Vibrio strains responsible for mortalities of Ostrea edulis larvae in our area (Bolinches et al. 1986, Lodeiros et al. 1987).

The genus Vibrio has received much attention in recent years, resulting in an increase in the number of the species recognized. Eight of these species have been described as pathogens of fish and shellfish: $V$. anguillarum, $V$. ordalii (Schiewe et al. 1981) (formerly $V$. anguillarum biotype II, Harrell et al. 1976), $V$. tubiashii (Hada et al. 1984), V. damsela (Love et al. 1981), V. vulnificus biotype II (Tison et al. 1982) (formerly $V$ anguillarum type $B$ and $V$. anguillicida, Muroga et al. 1976, Nishibuchi et al. 1980), V. carchariae (Grimes et al. 1984), V. salmonicida (Egidius et al. 1986), and $V$. cholerae non-O1 (Muroga et al. 1979, Yamanoi et al. 1980).

Vibrio anguillarum, $V$. tubiashii, $V$. ordalii, and $V$. damsela share a great number of phenotypic characteristics, but they can be distinguished from each other using phenotypic traits. One current problem is whether the bacterium $V$ ordalii should be regarded as $V$. anguillarum biotype II or whether it should be recognized as a separate species based on a $60 \%$ DNA homology with $V$. anguillarum (Schiewe et al. 1981. Tajima et al. 1985). We think that the strong serological cross-reactions of $V$ ordalii with the serotype $O 2$ of $V$. anguillarum (Ezura et al. 1980, Tajima et al. 1985, Toranzo et al. $1987 \mathrm{~b}$ ) together with the results of DNADNA hybridization, support the conclusion that $V$. ordalii is merely a biotype of $V$, anguillarum.

We have investigated by numerical taxonomy
(Unweighted Pair Group Method with Arithmetic averages, UPGMA; Sneath 1972) the relationship among Vibrio anguillarum, $V$. tubiashii, and the estuarine vibrios using a total of 341 strains isolated from diseased fish and shellfish as well as from water, sediment, phyto-and zooplankton (Fouz et al. 1990). Twelve defined phena of environmental vibrios were obtained, their similarity values with $V$, anguillarum and $V$. tubiashii ranged from 77 to $83 \%$. Most of these vibrios corresponded to different biotypes of $V$. splendidus and $V$. pelagius (Fouz et al. 1990). Simílar results were reported by Larsen $(1982,1983)$ and Bryant et al (1986). All of these findings suggest that the environmental vibrios represent phenotypic variants of a major and unique group which should be named $V$. anguillarum-like or atypicai $V$. anguiliarum. The $V$. angunlarum-like organisms differ from $V$. anguillarum in one or more of the following phenotypic traits: arginine dihydrolase, fermentation of sucrose, arabinose, and mannitol, gelatin hydrolysis, and resistance to ampicillin.

It is noteworthy that members of this group of vibrios ( $V$. splendidus - V. pelagius) have recently been isolated in pure or mixed cultures from dead marine fishes cultured in the Atlantic Coast of Spain and Norway (Toranzo, Fouz \& Gravningen, unpublished data). In fact, we have demonstrated that a strain of $V$. splendidus was implicated in a new pathologic syndrome of bacterial and viral etiology that occurred in both juvenile and adult turbot in different hatcheries in our area (Lupiani et al. 1989a). Experimental infections confirmed the pathogenicity of this $V$. splendidus strain (Lupiani et al, 1989b) which differed from $V$. anguillarum in its inability to ferment sucrose and mannitol and to hydrolyse gelatin.

On the basis of rRNA phylogenic studies, McDowell \& Colwell (1985) reported that the species $V$. anguillarum, $V$. damsela, and $V$. pelagius should be transferred into the newly proposed genus Listonella. However, further analysis of these data using a cluster program (Nearhos \& Fuerst 1987) did not support this designation because simultaneous analysis of sequence data from related vibrios such as $V$. ordalii and $V$. tubiashii were not conducted. Had McDowell and Colwell included these species in their study, their conclusions on the phylogenetic relationships might have been different.

\section{SEROLOGY}

The importance of serology in epizootiological and ecological studies of Vibrio anguillarum was emphasized by Pacha \& Kiehn (1969) who described 3 serotypes: Northwest salmonid vibrios (Serotype 1). European vibrios (Serotype 2), and Pacific herring vib- 
Table 1. Vibrio anguillarum. Vibriosis outbreaks in cultured fish and shellfish of different countries

\begin{tabular}{|c|c|c|}
\hline Species & Country & Source \\
\hline \multicolumn{3}{|l|}{ FISHES } \\
\hline \multicolumn{3}{|l|}{ Pacific salmon } \\
\hline \multirow[t]{6}{*}{ Oncorhynchus kisutch } & USA & Rucker et al. (1953) \\
\hline & & Fryer et al. (1972) \\
\hline & & Harrell et al. (1976) \\
\hline & & Strout et al. (1978) \\
\hline & Japan & Tajima et al. $(1981,1985)$ \\
\hline & Spain & Toranzo et al. (1987a) \\
\hline O. keta, O. nerka, O. gorbuscha & Canada & Evelyn (1971) \\
\hline O. masou, O. rhodurus & Japan & Tajima et al. (1985) \\
\hline \multirow[t]{2}{*}{ O. tshawytscha } & USA & Cisar \& Fryer (1969) \\
\hline & Canada & Evelyn (1971) \\
\hline \multicolumn{3}{|l|}{ Atlantic salmon } \\
\hline Salmo salar & Norway & Håstein \& Holt (1972) \\
\hline \multicolumn{3}{|l|}{ Trout } \\
\hline Oncorhynchus mykiss & USA & Ross et al. (1968) \\
\hline \multirow[t]{10}{*}{ (formerly Salmo gairdneri) } & Japan & Muroga \& Egusa (1973) \\
\hline & & Kitao et al. (1983) \\
\hline & & Tajima et al. (1985) \\
\hline & Italy & Giorgetti \& Ceschia (1982) \\
\hline & Norway & Holt $(1970)$ \\
\hline & & Egidius \& Andersen (1977) \\
\hline & Denmark & Larsen (1983) \\
\hline & & Larsen \& Mellergaard (1984) \\
\hline & & Sørensen \& Larsen (1986) \\
\hline & Spain & Toranzo et al. (1987a) \\
\hline Salmo trutta & Scotland & Smith (1961) \\
\hline & & Håstein \& Smith (1.977) \\
\hline \multicolumn{3}{|l|}{ Turbot } \\
\hline Scophthalmus maximus & Scotland & Horne e al. (1977) \\
\hline & Spain & Devesa et al. (1985) \\
\hline & & Toranzo et al. (1987a) \\
\hline \multicolumn{3}{|l|}{ Striped bass } \\
\hline Morone saxatilis & USA & Toranzo et al. (1983) \\
\hline \multicolumn{3}{|l|}{ Winter flounder } \\
\hline Pseudopleuronectes americanus & USA & Levin et al. $(1972)$ \\
\hline \multicolumn{3}{|l|}{ Cod } \\
\hline Gadus morhua & Norway & Egidius \& Andersen (1984) \\
\hline & Denmark & Larsen (1983) \\
\hline & & Larsen \& Jensen (1979) \\
\hline & & Larsen \& Mellergaard (1984) \\
\hline & & Sørensen \& Larsen (1986) \\
\hline \multicolumn{3}{|l|}{ Red sea-bream } \\
\hline Pagrus major & Japan & Muroga \& Tatani (1982) \\
\hline \multicolumn{3}{|l|}{ European eel } \\
\hline Anguilla anguilla & Norway & Rodsaether et al. (1977) \\
\hline \multicolumn{3}{|l|}{ Japanese eel } \\
\hline Anguilla japonica & Japan & Kitao et al. (1983) \\
\hline & & Tajima et al. (1985) \\
\hline \multicolumn{3}{|l|}{ Saithe } \\
\hline Pollachius virens & Norway & Egidius \& Andersen (1978) \\
\hline \multicolumn{3}{|l|}{ Gilthead sea-bream } \\
\hline Sparus aurata & Israel & Paperna et al. (1977) \\
\hline \multicolumn{3}{|l|}{ Sea mullet } \\
\hline Mugil cephalus & Scotland & Rodgers \& Burke (1981) \\
\hline
\end{tabular}


Table 1 (continued)

\begin{tabular}{|c|c|c|}
\hline Species & Country & Source \\
\hline \multicolumn{3}{|l|}{ FISHES } \\
\hline \multicolumn{3}{|l|}{ Seriola } \\
\hline \multirow[t]{2}{*}{ Seriola quinqueradiata } & Japan & Jo et al (1979) \\
\hline & & Tajima et al. (1985) \\
\hline \multicolumn{3}{|l|}{ Channel catfish } \\
\hline Ictalurus punctatus & USA & Lewis (1985) \\
\hline \multicolumn{3}{|l|}{ Milkfish } \\
\hline \multirow[t]{2}{*}{ Chanos chanos } & Taiwan & Huang (1977) \\
\hline & & Chen et al. (1985) \\
\hline \multicolumn{3}{|l|}{ Ayu } \\
\hline \multirow[t]{4}{*}{ Plecoglossus altivelis } & Japan & Muroga \& Egusa $(1967,1970)$ \\
\hline & & Mifuchi et al. (1983) \\
\hline & & Tajima et al. (1985) \\
\hline & Taiwan & Kuo et al. (1976) \\
\hline \multicolumn{3}{|l|}{ Tilapia } \\
\hline Oreochromis aureus & Kuwait & Tareen $(1984)$ \\
\hline \multicolumn{3}{|l|}{ MOLLUSCS ${ }^{\alpha}$} \\
\hline \multicolumn{3}{|l|}{ European oyster } \\
\hline \multirow[t]{4}{*}{ Ostrea edulis } & USA & DiSalvo et al (1978) \\
\hline & Great Britain & Jeffries (1982) \\
\hline & Spain & Bolinches et al. (1986) \\
\hline & & Lodeiros et al. (1987) \\
\hline \multicolumn{3}{|l|}{ Japanese oyster } \\
\hline \multirow[t]{3}{*}{ Crassostrea gigas } & USA & DiSalvo et al. (1978) \\
\hline & Australia & Garland et al. (1983) \\
\hline & Great Britain & Jeffries (1982) \\
\hline \multicolumn{3}{|l|}{ American oyster } \\
\hline \multirow[t]{5}{*}{ Crassostrea virginica } & USA & Tubiash et al. $(1965,1970)$ \\
\hline & & Elston (1979) \\
\hline & & Elston et al (1981) \\
\hline & & Brown \& Losee (1978) \\
\hline & & Brown (1981) \\
\hline \multicolumn{3}{|l|}{ Clam } \\
\hline Mercenaria mercenaria & USA & Tubiash et al $(1965,1970)$ \\
\hline \multicolumn{3}{|l|}{ CRUSTACEA } \\
\hline \multicolumn{3}{|l|}{$\begin{array}{l}\text { Lobster } \\
\text { Homarus americanus }\end{array}$} \\
\hline Homarus americanus & USA & Bowser et al. (1981) \\
\hline \multicolumn{3}{|l|}{ Shrimp } \\
\hline Penaeus sp. & USA & Lewis (1979) \\
\hline
\end{tabular}

rios (Serotype 3). Since then, several serotyping systems based on the slide agglutination method with thermostable $\mathrm{O}$ antigens have been developed. Up to 1986, 3 serotypes were recognized in Norway (Johnsen 1977), 2 or 3 in the United States (Harrell et al. 1976, Strout et al. 1978), and 9 in Japan (Kitao et al. 1984). Sørensen \& Larsen (1986) recommended an international harmonization of the diagnostic efforts and presented a new antigenic typing scheme in which 10 distinct $O$ serotypes of $V$. anguillarum were recog- nized. However, most of the isolates associated with diseased fish throughout the world belonged to the serotypes $\mathrm{O} 1$ and $\mathrm{O} 2$ (see references in Table 2), As shown in Table 2, these 2 major pathogenic serotypes have been given different names by different authors, making the coordination of epizootiological studies and vaccination programs in the different countries difficult. Actually, with the exception of laboratories in Japan and Taiwan, most of the investigators follow the scheme of Sørensen \& Larsen. This scheme is in agree- 
Table 2. Vibrio anguillarum. Serotyping systems based on the thermostable $O$ antigens. Designations of the major pathogenic serotypes used by various authors

\begin{tabular}{|c|c|c|c|}
\hline Country & \multicolumn{2}{|c|}{ Serotype designation } & \multirow{2}{*}{$\begin{array}{l}\text { Source } \\
\text { Johnsen (1977) }\end{array}$} \\
\hline Europe & Group 1 & Group 2 & \\
\hline & $\mathrm{O} 2$ & 01 & Sorensen \& Larsen (1986) \\
\hline \multirow[t]{3}{*}{ USA } & European vibrios & Northwest salmonid vibrios & Pacha \& Kiehn (1969) \\
\hline & Type II & Type I & Harrell et al. (1976) \\
\hline & 569 Group & 775A Group & Strout et al. (1978) \\
\hline \multirow[t]{3}{*}{ Japan } & I & III & Kusuda et al. $(1975,1981)$ \\
\hline & A & $\mathrm{C}$ & $\begin{array}{l}\text { Aoki \& Kitao }(1978) \\
\text { Kitao et al. }(1983,1984)\end{array}$ \\
\hline & $\mathrm{J}-\mathrm{O}-1$ & $\mathrm{~J}-\mathrm{O}-3$ & $\begin{array}{l}\text { Ezura et al }(1980) \\
\text { Tajima et al. }(1985)\end{array}$ \\
\hline Taiwan & $\mathrm{T}-\mathrm{O}-\mathrm{V}$ & $\mathrm{T}-\mathrm{O}-\mathrm{I}$ & $\begin{array}{l}\text { Chang \& Kou (1983) } \\
\text { Song et al. (1988) }\end{array}$ \\
\hline
\end{tabular}

ment with the American serotyping system but it uses Arabic rather than Roman numerals and it employs the prefix ' $O$ ' to avoid confusion with capsular or flagellar antigens.

Our studies on the serological relationship within Vibrio anguillarum strains indicated that the isolates from $O 1$ serotype constitute a homogenous group by the Double Immunodiffusion (IDD), Dot Blot Assay (DBA), and Enzyme Linked Immunoabsorbent Assay (ELISA) methods (Bolinches et al. 1990). However, within serotype $\mathrm{O} 2,2$ different patterns of serological reactions were detected based on $\mathrm{O}$ antigens. These 2 antigenic entities were designated as the $O 2 \alpha$ and $\mathrm{O} 2 \beta$ subgroups. More recently, we have extended this research using the DBA on a large number of isolates from different sources and geographic areas (Fouz et al. 1989). It was found that the majority of $V$. anguillarum O2 strains $(75 \%)$ belonged to the O2 $\alpha$ subgroup and that this subgroup occurred in both salmonid and non salmonid fishes. In contrast, the $O 2 \beta$ strains occurred mainly in non salmonid fishes (turbot, saithe, cod, and striped bass). In addition, we demonstrated that these 2 subgroups $(O 2 \alpha$ and $O 2 \beta)$ were the same as subgroups $\mathrm{O} 2 \mathrm{a}$ and $\mathrm{O} 2 \mathrm{~b}$ detected by Danish investigators using immunoelectrophoretic methods (Rasmussen 1987). The serological heterogeneity evident in strains of serotype $\mathrm{O} 2$ was greater than that found in serotype $\mathrm{O} 1$ and was consistent with their greater variability in phenotypic characteristics (Fouz et al. 1989).

Since 1983, several epizootics of vibriosis affecting turbot, coho salmon and rainbow trout have occurred in different locations on the Galician Coast (Table 3). Studies on the Vibrio anguillarum serotypes involved indicated that until 1987, regardless of the species of fish and culture site, practically all of the $V$. anguillarum strains isolated belonged to serotype $\mathrm{O} 1$. How- ever, from 1988 onwards isolations of the $V$. anguillarum serotype $\mathrm{O} 2 \alpha$ were made from turbot. This serotype has been reported as the predominant type in marine fishes in Denmark (Sørensen \& Larsen 1986) and Norway (Wiik et al. 1989, Toranzo, Barja, Fouz \& Gravningen, unpubl.) and its occurrence on the Galician coast may be a consequence of importations of fingerlings from nordic countries.

As shown in Table 3 , all serotype 01 strains were arabinose positive, and harbored the 47 megadaiton virulence plasmid similar to the pJM1 plasmid reported in Vibrio anguillarum 775 (Crosa 1980, Tolmasky et al. 1985. Toranzo et al. 1987a). In contrast, the O2 strains failed to ferment arabinose and lacked high molecular weight plasmids, indicating a chromosome-mediated virulence mechanism (Lemos et al. 1988). Similar findings were reported by Wiik et al. (1989) for the $\mathrm{O} 1$ and $\mathrm{O} 2 \mathrm{~V}$. anguillarum strains isolated in Norway. However, the existence of some $V$. anguillarum $O 1$ strains lacking virulence plasmid (Lemos et al. 1988, Wiik et al. 1989) indicates that the presence of pJM1-like plasmids cannot be used as an indicator of serology.

Interestingly, our data on the serological relationships between the pathogenic serotypes of Vibrio anguillarum and the environmental vibrios (Fouz et al. 1990 ) indicated that all of the antisera raised against strains from each of the $V$. anguillarum-like phena displayed cross-reactions with $V$. anguillarum serotype $\mathrm{O} 2$ but not with serotype $\mathrm{O} 1$.

\section{EPIZOOTIOLOGICAL STUDIES}

The reservoir of the pathogenic serotypes of Vibrio anguillarum in the aquatic environment is uncertain because few data on the ecology and distribution of organism exist. 
Table 3. Vibrio anguillarum. Epizootics in 8 different seawater ongrowing facilities (designated as $A$ to $H$ ) located on the Northwest Atlantic Coast of Spain. Occurrence of pathogenic serotypes. Positive reaction $(+)$ and presence of the virulence plasmid; NT. not tested

\begin{tabular}{|c|c|c|c|c|c|c|}
\hline Strain & Host & Ongrowing farm & Year & Serotype & $\begin{array}{c}\text { Arabinose } \\
\text { fermentation }\end{array}$ & $\begin{array}{l}\text { Virulence } \\
\text { plasmid }\end{array}$ \\
\hline $\mathrm{R}-82$ & Turbot & $A$ & 1983 & 01 & + & + \\
\hline$R V \cdot 22$ & Turbot & $\mathrm{B}$ & 1985 & $\mathrm{O} 2 \beta^{\alpha}$ & - & - \\
\hline RT -32 & Turbot & A & 1985 & $\mathrm{O} 1$ & + & + \\
\hline $\mathrm{SO}-86.3$ & Pacific salmon & C & 1986 & 01 & + & + \\
\hline SO-86.9 & Pacific salmon & C & 1986 & 01 & + & + \\
\hline TM-14 & Rainbow trout & $\mathrm{C}$ & 1986 & 01 & + & + \\
\hline TM-52 & Rainbow trout & C & 1986 & 01 & + & + \\
\hline RP-13 & Turbot & $\mathrm{D}$ & 1987 & 01 & + & + \\
\hline RP-51 & Turbot & $\mathrm{D}$ & 1987 & 01 & + & + \\
\hline$R P-63$ & Turbot & $\mathrm{D}$ & 1987 & 01 & + & + \\
\hline RM-21 & Turbot & $E$ & 1.987 & 01 & + & + \\
\hline$R P-81$ & Turbot & $\mathrm{D}$ & 1987 & 01 & + & + \\
\hline $\mathrm{RC}-52$ & Turbot & $\mathrm{F}$ & 1988 & 01 & + & + \\
\hline $\mathrm{RC}-71$ & Turbot & $\mathrm{F}$ & 1988 & $\mathrm{O} 2 \alpha$ & + & - \\
\hline RG-1 11 & Turbot & $G$ & 1988 & $\mathrm{O} 2 \alpha$ & - & - \\
\hline$R G-121$ & Turbot & $\mathrm{G}$ & 1988 & $\mathrm{O} 2 \alpha$ & - & - \\
\hline $\mathrm{RC}-91$ & Turbot & $F$ & 1988 & 01 & + & + \\
\hline $\mathrm{RO}-32$ & Turbot & C & 1988 & 01 & + & NT \\
\hline RG-133 & Turbot & $G$ & 1988 & $02 \alpha$ & - & - \\
\hline $\mathrm{RG}-141$ & Turbot & $\mathrm{G}$ & 1988 & O1 & + & + \\
\hline $\mathrm{RG}-161$ & Turbot & $\mathrm{G}$ & 1988 & 01 & + & + \\
\hline $\mathrm{RG}-181$ & Turbot & $\mathrm{G}$ & 1989 & $02 \alpha$ & - & - \\
\hline RH-81 & Turbot & $E$ & 1990 & $\mathrm{O} 1$ & + & + \\
\hline TH- 10.1 & Rainbow trout & $\mathrm{C}$ & 1990 & $\mathrm{O} 1$ & + & + \\
\hline $\mathrm{RPH}-23.1$ & Turbot & $\mathrm{H}$ & 1990 & $\mathrm{O} 2 \alpha$ & - & - \\
\hline RC- 16.1 & Turbot & $\mathrm{F}$ & 1990 & O1 & + & NT \\
\hline
\end{tabular}

Muroga et al. (1984) conducted a 4 yr study on the incidence of Vibrio anguillarum in wild ayu fingerlings and found that fish caught in seawater or brackish water harbored the microorganism at significantly higher rates than fingerlings caught a in freshwater lake. From a total of 9574 fish examined, $V$. anguillarum was detected in only 168 (1.7\%). In addition, infection tests revealed that only the strains belonging to the major pathogenic serotypes $\mathrm{J}-\mathrm{O}-1$ and $\mathrm{J}-\mathrm{O}-3$ (i.e $\mathrm{O} 2$ and $\mathrm{O} 1$, respectively), were virulent.

Muroga et al. (1986) investigated the prevalence of Vibrio anguillarum in the environment and observed that this organism was often detected from seawaters of the Inland Sea of Japan but not from the freshwater of ayu ponds. This held true even during vibriosis outbreaks. Interestingly, the majority of the strains were non-pathogenic and non-typable as to O-serotype.

With ayu, the usual source of the infection in freshwater was the fingerlings captured from marine or brackish water (Muroga et al. 1984, 1986). However on some occasions it was shown that the marine rotifer (Brachionus plicatilis), fed to ayu larvae, was the source of the pathogen in the freshwater ponds (Tabata et al.
1982). Similarly, it seems probable that vibriosis outbreaks in trout cultured in freshwater in Italy (Giorgetti $\&$ Ceshia 1982) were due to the use of wet marine fish as food.

Sørensen \& Larsen (1986), in a 5 yr study, examined more than 500 Vibrio anguillarum strains from feral and farmed fish, as well as from seawater, sediment, and invertebrates. They found that whereas the serotypes $\mathrm{O} 1$ and $\mathrm{O} 2$ were most commonly isolated from diseased fish (in cultured salmonid fish and feral marine fish, respectively), the environmental strains belonged to the remaining 8 serotypes or were nontypable. Similar findings were observed in another seroepizootiological survey conducted by Larsen et al. (1988) in rainbow trout at a Danish mariculture facility and in feral fish caught close to the facility. Similarly, Tajima et al. (1988) studied the distribution of $V$. anguillarum in coho salmon and their culture environment and detected $58 \mathrm{~V}$. anguillarum from a total of 5337 Vibrio isolates obtained. Only the strains originating from pen-reared fish corresponded to the pathogenic serotype J-O-3 (i.e. serotype 011 and the isolates from seawater, mud, 
and plankton corresponded to serotype J-O-8, a lowvirulence serotype.

It is noteworthy that in the majority of these epizootiological studies, the pathogenic serotypes of Vibrio anguillarum could not be detected from carrier fish or environmental samples without an initial concentration or enrichment of the samples. This probably explains why, using direct isolation on agar plates, we were unable to recover serotypes $\mathrm{O} 1$ and $\mathrm{O} 2$ from the marine environment (Fouz et al. 1990).

Other epizootiological investigations focused on the factors affecting the stability of Vibrio anguillarum in the aquatic environment. Muroga \& Egusa (1967), Evelyn (1971), and Itami \& Kusuda (1984) evaluated the viability of $V$, anguillarum in different $\mathrm{NaCl}$ concentrations and found that optimum growth occurred in 1 to $2 \%$ salt. Larsen (1984) studied the interaction of environmental parameters such as temperature, $\mathrm{pH}$, salinity, and incubation time on the growth of different isolates of $V$. anguillarum. Although their results varied according to the origin of the strains examinated, in general the optimal values were $\mathrm{pH} 7,25^{\circ} \mathrm{C}$, and $2 \%$ $\mathrm{NaCl}$. Our survival studies in estuarine water (Toranzo et al. 1982) indicated that $V$. anguillarum had the ability to multiply within the first $4 \mathrm{~d}$ of the experiment. After this, there was a gradual decline in cell numbers, viable cells being detectable after more than $100 \mathrm{~d}$. Muroga et al. (1986) found that the microorganism persisted in seawater for more than $15 \mathrm{~d}$ without a decrease in viable counts; however, it perished within 3 to $5 \mathrm{~h}$ in freshwater.

It should be emphasized that in these environmental studies an adaptive property among isolates of Vibrio anguillarum to distinct $\mathrm{NaCl}$ concentrations and temperatures was observed. Therefore, in agreement with Larsen (1984), we consider that $V$. anguillarum strains from various geographic areas have their own temperature and salinity optima and they occur in their niches at a characteristic density (viable cells $\mathrm{ml}^{-1}$ ), usually showing a moderate yearly variation.

Another important ecological parameter determining the growth of Vibrio anguillarum is the load of organic matter in the water. Organic matter provides nutrients and solid surfaces for attachment and colonization (first step in the development of an infection). In order to evaluate the impact of organic pollution on the prevalence of $V$. anguillarum in the aquatic environment, Danish investigators (Larsen 1982, Larsen \& Willeberg 1984) monitored over a 3 yr period the annual cycle of this microorganism in waters and sediments of coastal areas with different degrees of pollution. In general, the number of presumptive $V$, anguillarum in polluted areas was 10 to 100 per $\mathrm{ml}$ of water and $10^{3}$ to $10^{4}$ per $\mathrm{g}$ of sediment whereas the corresponding values for the unpolluted sites were 1 to 10 per $\mathrm{ml}$ water and $10^{2}$ to
$10^{3}$ per g sediment. According to these results, fish living in polluted areas are exposed to a 10 times higher risk of vibriosis. The data suggest that the $V$. anguillarum content of the water might be used to indicate the level of organic pollution and the risk of infectious disease in wild and cultured fish. Larsen \& Willeberg (1984) recommended that $10^{4} \mathrm{~V}$. anguillarum per $100 \mathrm{ml}$ should be the upper acceptable level for selecting mariculture sites. However, we should point out that based on the tests used by these authors for the identification of the Vibrio isolates, $V$. anguillarum-like organisms probably contributed to the bacterial counts.

It has been suggested that studies on the ecology of Vibrio anguillarum should focus on virulence markers such as factors associated with host adhesion and colonization (Larsen et al. 1988). Hemagglutinating activity in addition to hydrophobic surface properties are sometimes associated with virulence. These authors reported that most of the $\mathrm{O} 1$ strains were non-hemagglutinating and that the majority of the $\mathrm{O} 2$ strains agglutinated a broad spectrum of erythrocytes. They also found that the $\mathrm{O} 1$ isolates were more hydrophobic than the $\mathrm{O} 2$ strains. These findings differ from our results (Santos et al. 1990) which showed that some $V$. anguillarum serotype $\mathrm{O} 1$ isolates from diseased fish displayed hemagglutinating activity and that the $\mathrm{O} 2$ isolates displayed more hydrophobic tendencies than serotype $O 1$ strains. Because of these discrepancies (which may be attributed to the different origin of the isolates) we consider that these properties would be unreliable as virulence markers in seroepizootiological studies.

\section{CONCLUSIONS}

All the epizootiological data indicate that Vibrio anguillarum can be ubiquitous in the marine environment, but that only certain serotypes (e.g. O1 and O2) in the $V$. anguillarum population (which occur in a very low proportion in a particular reservoir) possess the genetic potential to successfully establish themselves in fish and cause disease (generally in fish with a lowered resistance). This raises the question whether all serotypes of $V$. anguillarum can be considered as opportunistic fish pathogens. In addition, the antigenic heterogeneity detected within serotype $\mathrm{O} 2$ emphasizes the importance of a harmonizing the terminology used in seroepizootiological studies so that vaccination programs in the different countries can be facilitated.

The existence in the marine environment of Vibrio anguillarum-like organisms, some of which are associated with fish disease, indicates the need for further investigations to determine: (1) the precise taxonomic position of these groups of vibrios, (2) their possible serological relationship with the environmental sero- 
types of $V$ anguillarum, and (3) their potential as pathogens for fish and shellfish

The ecological studies on the stability of Vibrio anguillarum in different water types demonstrated that the seawater is an important vehicle of transmission of this microorganism and, hence, that epizootics of vibriosis can take place far away from the source of infection.

Acknowledgements. The authors thank Y Santos, M. L. Lemos and B. Fouz for their help and criticisms in the preparation of this manuscript. This work was supported by grant PB87-1027 from the Dirección General de Investigación Cientíifica y Técnica (DGICYT), and grant AQ-0018/84 from the Comisión Asesora de Investigación Científica y Técnica (CAICYT), Ministerio de Educación y Ciencia, Spain.

\section{LITERATURE CITED}

Aoki, T., Kitao, T. (1978). Vibriosis of Ayu. Fish Pathol. 13: $19-24$

Bolinches, J., Toranzo, A. E., Silva, A., Barja, J. L. (1986). Vibriosis as the main causative factor of heavy mortalities in the oyster culture industry in Northwestern Spain. Bull. Eur Ass. Fish Pathol. 6: 1-4

Bolinches, J., Lemos, M. L., Fouz, B., Cambra, M., Larsen, J. L., Toranzo, A. E. (1990). Serological relationships among Vibrio anguillarum strains. J. aquat. Anim Hlth 2: 12-20

Bowser, P. R., Rosemar, R., Reiner, C. R. (1981). A preliminary report of vibriosis in cultured american lobster, Homarus americanus. J. Invertebr. Path. 37: 80-85

Brown, C. (1981). A study of two shellfish-pathogenic Vibrio strains isolated from a Long Island hatchery during a recient outbreak of disease. J. Shellfish Res. 1. 83-87

Brown, C., Losee, E. (1978). Observations on natural and induced epizootics of vibriosis in Crassostrea virginica larvae. J. Invertebr Path. 31. 41-47

Bryant, T. N., Lee, J. V., West, P. A., Colwell, R. R. (1986). Numerical classification of species of Vibrio and related genera. J. appl. Bacteriol. 61: 437-496

Chang, C. Y., Kou, G. H. (1983). Study on serotypes of Vibrio anguillarum isolated from cultured fishes in Taiwan. Council for Agricultural Planning and Development (C.A.P.D.), Fish. Ser. 9: 22-30

Chen, T M., Tsai, S. S., Chen, S. C. (1985). Study on Vibrio anguillarum infection in cuitured milkfish (Chanos chanos) in Taiwan. Council of Agriculture (COA), Fish Ser No. 4, Fish Dis. Res. (VII), Taipei p. 27-37

Cisar, J. O., Fryer, J. L. (1969). An epizootic of vibriosis in Chinook salmon. Bull. Wildl dis. Ass. 5: 73-76

Crosa, J. H. (1980). A plasmid associated with virulence in the marine fish pathogen Vibrio angullarum specifies an ironsequestering system. Nature, Lond. 284: 566-568

Devesa, S., Toranzo, A. E., Barja, J. L. (1985). First report of vibriosis in turbot (Scophthalmus maximus) cultured in Northwestern Spain. In: Ellis, A. E. (ed.) Fish and shellfish pathology. Academic Press, London, p. 131-140

DiSalvo, L. H., Bleoka, J., Zebal, R. (1978). Vibrio anguillarum and larval mortality in a California coastal shellfish hatchery. Appl. environ. Microbiol. 35: 2219-2221

Egidius, E., Andersen, K. (1977). Norwegian reference strains of Vibrio anguillarum. Aquaculture 10: 215-219

Egidius, E., Andersen, K. (1978). Host-specific pathogenicity of strains of Vibrio anguillarum isolated from rainbow trout
(Salmo gairdneri) and saithe (Pollachius virens). J. Fish Dis. 1: $45-50$

Egidius, E., Andersen, K. \{1984\}. Disease problems in cod rearing. In: Dahl, E., Danielsen, D., Moksness, E., Solemdal, P. (eds.) The propagation of cod Gadus morhua, L. vol. 1. Flødevigen Rapp., Bergen, p. 761-769

Egidius, E. Wiik, R. Andersen, K., Hoff, K. A., Hjeltness, B. (1986). Vibrio salmonicida sp. nov., a new fish pathogen. Int. J. system. Bact. 36: 518-520

Elston, R. (1979). Economically important bivalve diseases and their control. Riv. Ital. Pisic. Ittiopat. 14: 47-51

Elston, R., Leibovitz, L., Relyea, D., Zatila (1981). Daignosis of vibriosis in a commercial oyster hatchery epizootic: diagnostic tools and managements features. Aquaculture 24: $53-62$

Evelyn, T. P. T (1971). First records of vibriosis in Pacific salmon cultured in Canada, and taxonomic status of the responsible bacterium Vibrio anguillarum. J. Fish. Res. Bd Can 28: 517-525

Ezura, Y., Tajima, K., Yoshimizu, M., Kimura, T (1980) Studies on the taxonomy and serology of causative organisms of $f_{1 s h}$ vibriosis. Fish pathol. 14: 1.67-179

Fouz, B., Conchas, R. F., Bolinches, J., Romalde, J. L., Barja, J L., Toranzo, A. E. (1990). Relationship among pathogenic Vibrio anguillarum and $V$, tubiashii with environmental vibrios. In: Perkins, F. O., Cheng, T. C. (eds.) Pathology in marine science. Academic Press, New York, p. 77-89

Fouz, B., Conchas, R. F., Lemos, M. L., Toranzo, A. E. (1989) Antigenic entities within Vibrio anguillarum serotype $\mathrm{O} 2$ determined by dot blot assay. Abstract IV. EAFP International Conference. Santiago de Compostela, Spain, p. 105

Fryer, J. L., Nelson, J. S., Garrison, R. L. (1972). Vibriosis in fish. Prog. Fish. Fd Sci. 5: 129-133

Garland, C. D., Nash, G. V., Sumner, C. E., McMeekin, T A. (1983). Bacterial pathogens of oyster larvae (Crassostrea gigas) in a Tasmanian hatchery. Aust. J. Mar Freshwat Res. 34: 483-487

Giorgetti, G., Ceschia, G. (1982). Vibriosis in rainbow trout, Salmo gairdneri Richardson, in fresh water in northeastern Italy. J. Fish Dis. 5: 125-130

Grimes, D. J., Stemmler, J., Hada, H., May, E. B., Maneval, D., Hetrick, F. M., Jones, R. T., Stoskopf, M. (1984). Vibrio species associated with mortality of sharks held in captitivity. Microb. Ecol. 10: 271-282

Hada, H. S., West, P. A., Lee, J. V., Stemmler, J., Colwell, R. R. (1984). Vibrio tubiashii sp. nov. a pathogen of bivalve molluscs. Int. J. system. Bact. 34: 1-4

Harrell, L. W., Novotny, A. J., Schiewe, M. H., Hodgins, H. O. (1976). Isolation and description of two vibrios pathogenic to Pacific salmon in Puget Sound, Washington. Fish. Bull U.S. $74: 447-449$

Håstein, T., Holt, G. (1972). The occurrence of vibrio disease in wild norwegian fish. J. Fish Biol. 4: 33-37

Håstein, T., Smith, J. E. (1977). A study of Vibrio anguillarum from farmed and wild fish using principal. components analysis. J. Fish Biol. 11 69-75

Holt, G. (1970). Vibriosis (Vibrio anguillarum) as an epizootic disease in rainbow trout (Salmo gairdneri). Acta Vet scand. 11: 600-603

Horne, M. T., Richards, R. H., Roberts, R. J., Smith, P. C (1977). Peracute vibriosis in juvenile turbot Scophthalmus maximus. J. Fish Biol. 11: 355-361.

Huang, $Y$ H. (1977). Preliminary report of studies on bacterial disease of milkfish, Chanos chanos during winter Joint Commission for Rural Reconstruction, Fish Ser. 29: 50-54

Itami, T., Kusuda, R. (1984). Viability and pathogenicity of Vibrio anguillarum, in $\mathrm{NaCl}$ solutions of various concen- 
trations, isolated from ayu cultured in freshwater. J. Shimonoseki Coll. Fish. 32: 33-39

Jeffries, V. E. (1982). Three Vibrio strains pathogenic to larvae of Crassostrea gigas and Ostrea edulis. Aquaculture 29: 201-226

Jo, Y., Ohnishi, K., Muroga, K. (1979). Vibrio anguillarum isolated from cultured yellowtail. Fish Pathol. 14: 43-47

Johnsen, G. S. (1977). Immunological studies on Vibrio anguillarum. Aquaculture 10: 221-230

Kitao, T., Aoki, T., Fukudome, M., Kawano, K., Wada, Y., Mizuno, Y. (1983). Serotyping of Vibrio anguillarum from diseased freshwater fish in Japan. J. Fish Dis. 6: 175-181

Kitao, T., Aoki, T., Muroga, K. (1984). Three new O-serotypes of Vibrio anguillarum. Bull. Jap. Soc. Sci. Fish. 50:1955

Kuo, S. C., Chung, H. Y., Kou. (1976). Vibrio anguillarum isolated from a vibrio disease of fresh-water cultured ayu, Plecoglossus altivelis. J. Fish. Soc., Taiwan 4: 21-24

Kusuda, R., Kawai, K., Sako, H. (1975). Studies on taxonomy of fish pathogenic Vibrios. II. examination on serological characteristics. Proc. Autumn Annual Meeting of Japanese Society of Scientific Fisheries, Tokyo, p. 71

Kusuda, R., Kawai, K., Sako, H. (1981). Classification of vibrios isolated from diseases fishes. II. On the serological properties. Rep. Usa Mar. Biol. Inst. 3: 89-95

Larsen, J. L. (1982). Vibrio anguillarum: Prevalence in three carbohydrate loaded marine recipients and a control. Zentabl. Bakt. Hyg., I. Abt. Orig. C 3: 519-530

Larsen, J. L. (1983). Vibrio anguillarum: a comparative study of fish pathogenic, environmental, and reference strains. Acta Vet. scand 24: 456-476

Larsen, J. L. (1984). Vibrio anguillarum: influence of temperature, $\mathrm{pH}, \mathrm{NaCl}$ concentration and incubation time on growth. J. appl. Bacteriol. 57: 237-246

Larsen, J. L., Jensen, N. J. (1979). The ulcus-syndrome in Cod (Gadus morhua) II. A bacteriological investigation. Nord. Vet.-Med. 31: 289-296

Larsen, J. L., Mellergaard, S. (1984). Agglutination typing of Vibrio anguillarum isolates from diseased fish and from the environment. Appl. environ. Microbiol. 47: 1261-1265

Larsen, J. L., Willeberg, P. (1984). The impact of terrestrial and estuarial factors on the density of environmental bacteria (Vibrionaceae) and faecal coliforms in coastal water Zentbl Bakt. Hyg., I. Abt. Orig. B 179: 308-323

Larsen, J. L., Rasmussen, H. B., Dalsgaard, I. (1988). Study of Vibrio anguillarum strains from different sources with emphasis on ecological and pathogiological properties. Appl. environ. Microbiol. 54: 2264-2267

Lemos, M. L., Salinas, P., Toranzo, A. E., Barja, J. L., Crosa, J. H. (1988). A chromosome-mediated iron-uptake system in pathogenic Vibrio anguillarum strains. J. Bacteriol. 170 $1920-1925$

Levin, M. A., Wolke, R. E., Cabelli, V. J. (1972). Vibrio anguillarum as a cause of disease in winter flounder (Pseudopleuronectes americanus). Can. J. M:crobiol. 18: $1585-1592$

Lewis, D. H. (1979). Serology of shrimp pathogenic vibrios. In: Lewis, D. H., Leong, J. K. (eds.) Proc. 2nd Bien. Crust. Hlth Workshop. Texas A\&M University, Texas, p. 132-136

Lewis, D. H. (1985). Vibriosis in channel catfish, Ictalurus punctatus (Rafinesque). J. Fish Dis. 8: 539-545

Lodeiros, C., Bolinches, J., Dopazo, C. P., Toranzo, A. E (1987). Bacillary necrosis in hatcheries of Ostrea edulis in Spain. Aquaculture 65: 15-29

Love, M., Fisher, D. T., Hose, J. E., Farmer, J. J., Hickman, F W., Fanning, G. R. (1981). Vibrio damsela, a marine bacterium, causes skin ulcers on the damselfish Chromis punctipinnis. Science 214: 1140-1141
Lupiani, B., Dopazo, C. P., Ledo, A., Fouz, B., Barja, J. L. Toranzo, A. E. (1989a). A new syndrome of mixed bacterial and viral etiology in cultured turbot (Scophthalmus maximus, L.). J. Aquat. Anim Hlth 1. 197-204

Lupiani, B., Ledo, A., Dopazo, C. P., Baya, A., Toranzo, A. E., Barja, J. L. (1989b). Virulence of Vibrio splendidus and turbot reovirus (TRV) for three different fish species. Abstract IV EAFP International Conference. Santiago de Compostela, Spain, p. 103

McDowell, M. T., Colwell, R. R. (1985). Phylogeny of the Vibrionaceae, and recommendation for two new genera, Listonella and Shewanella. Syst. appl. Microbiol. 6: 171-182

Mifuchi, I., Yanagihara, Y., Shimizu, T., Ushiyama, M. (1983). Epidemiological studies of vibriosis of young ayu (Plecoglossus altivelis) in Hamana-lake. I. Identification and incidence of Vibrio anguillarum and their serotypes. Fish Pathol. 18: 19-25

Muroga, K., Egusa, S. (1967). Vibrio anguillarum from an endemic disease of ayu in lake Hamana. Bull. Jap. Soc. Sci. Fish. 33: 636-640

Muroga, K., Egusa, S. (1970). Vibrio anguillarum isolated from ayu in fresh-water farm-ponds. Fish Pathol. 5: 16-20

Muroga, K., Egusa, S. (1973). Studies on Vibrio anguillarum isolated from salt water and fresh water fishes. Fish Pathol 8: $9-25$

Muroga, K., Iida, M., Matsumoto, H., Nakai, T. (1986). Detection of Vibrio anguillarum from waters. Bull, Jap. Soc. Sci. Fish. 52: 641-647

Muroga, K., Takahashi, S., Yamanoi, H. (1979). Non-cholera Vibrio isolated from diseased ayu. Bull. Jap. Soc. Sci. Fish. 45: 829-834

Muroga, K., Tatani, M. (1982). Isolation of Vibrio anguillarum from juvenile red sea-bream (Pagrus major). Fish Pathol. 16: $211-214$

Muroga, K., Yamanoi, H., Hironaka, Y., Yamamoto, S., Tatani M., Jo, Y., Takahashi, S., Hanada, H. (1984). Detection of Vibrio anguillarum from wild fingerlings of ayu Plecoglossus altivelis. Bull. Jap. Soc. Sci. Fish. 50: 591-596

Muroga, K., Yasuhiko, J., Nishibuchi, R. M. (1976). Pathogenic Vibrio isolated from cultured eels. I. Characteristics and taxonomic status. Fish Pathol. 11: 141-145

Nearhos, S. P., Fuerst, J. A. (1987). Reanalysis of 5S rRNA sequence data for the Vibrionaceae with the clustan program suite. Curr. Microbiol. 15: 329-335

Nishibuchi, M., Muroga, K., Jo, Y (1980). Pathogenic Vibrio isolated from cultured eels. VI. Diagnostic tests for the disease due to the present bacterium. Fish Pathol. 14: $125-131$

Pacha, R. E., Kiehn, E. D. (1969). Characterization and relatedness of marine vibrios pathogenic for fish: physiology, serology, and epidemiology. J. Bacteriol, 100: 1242-1247

Paperna, I., Colorni, A., Gordin, H., Kissel, G. W (1977) Diseases of Sparus aurata in marine culture at Eilat. Aquaculture 10: 195-213

Rasmussen, H. B. (1987). Subgrouping of lipopolysaccharide O antigens from Vibrio anguillarum serogroup $\mathrm{O} 2$ by immunoelectrophoretic analyses. Curr. Microbiol. 16: 39-42

Rodgers, L. J., Burke, J. B. (1981). Seasonal variation in the prevalence of 'red spot' disease in estuarine fish with particular reference to the sea mullet, Mubil cephalus L. J. Fish Dis. 4: 297-307

Rodseather, M. C., Olafsen, J., Raa, J., Myhre, K., Steen, J. B. (1977). Copper as an initiating factor of vibriosis (Vibrio anguillarum) in eel (Anguilla anguilla). J. Fish Biol. 10 $17-21$

Ross, A. J., Martin, J. E., Bressler, V. (1968). Vibrio anguil- 
larum from an epizootic in rainbow trout (Salmo gairdneri) in USA. Bull. Off. int. Epizoot. 69: 1139-1148

Rucker, R. R., Earp, B. J., Ordal, E. J. (1953). Infectious diseases of Pacific salmon. Trans. Am. Fish. Soc. 83: 297-312

Santos, Y., Bandín, I. Nieto, I P., Bruno, D. W., Ellis, A. E.. Toranzo, A. E. (1990). Comparison of the cell surface hydrophobicity of bacterial tish pathogens by different procedures. In: Perkins, F. O., Cheng, T C. (eds.) Pathology in marine science. Academic Press, New York, p. $101-115$

Schiewe, M. H., Trust, T. J., Crosa, J. H. (1981). Vibrio ordalii sp. nov.: a causative agent of vibriosis in fish. Curr. Microbiol. 6: $343-348$

Smith, I. W. (1961). A disease of finnock due to Vibrio anguillarum. J. gen. Microbiol. 24: 247-252

Sneath, P. H. A. (1972). Computer taxonomy. In: Norris, J. R., Ribbons, D. W. (eds.) Methods in microbiology, vol. 7A. Academic Press, London, p. 29-98

Song: Y L. Chen, S. N, Kou, G. H. (1988). Serotyping of Vibrio anguillarum strains isolated from fish in Taiwan. Fish Pathol. 23: 185-189

Sorensen, U. B. S., Larsen, J. L. (1986). Serotyping of Vibrio anguillarum. Appl. environ. Microbiol. 51: 593-597

Strout, R. G., Sawyer, E. S., Loutermarsh, B. A. (1978). Pathogenic vibrios in confinement-reared and feral fishes of the Maine-New Hampshire coast. J. Fish. Res. Bd Can. 35: 403-408

Tabata, K., Karata, S., Ruiz, M. S. (1982). Studies on naturally occurring disease during the production of ayu (Plecoglossus altivelis) in seawater. II. Dynamics of Vibrio anguillarum. Fish Pathol. 17. 205-212

Tajima, K., Yoshimizu, M., Ezura, Y., Kimura, T. (1981). Studies on the causative organisms of vibriosis among the pen-cultured coho salmon Oncorhynchus kisutch in Japan. Bull. Jap. Soc. Sci. Fish. 47: 37-42

Tajima, K., Ezura, Y., Kimura, T (1985). Studies on the taxonomy and serology of causative organisms of fish vibriosis. Fish Pathol. 20: 131-142

Tajima, K., Ezura, Y., Kimura, T (1988). Distribution of Vibrio anguillarum in Otsuchi Bay as fish culture environments Fish Pathol. 23: 95-103

Responsible Subject Editor. Dr T. Evelyn, Nanaimo, B.C. Canada
Tareen, I. U. (1984). Vibriosis in Oreochromis aureus acclimatized to seawater: control and prophylaxis. Bull. Eur. Ass. Fish Pathol 4: 47-49

Tison, D. L., Nishibuchi, M., Greenwood, J. D., Seldler, R M. (1982). Vibrio vulnificus biogroup 2: new biogroup pathogenic for eels. Appl environ. Microbiol. 44: $640-646$

Tolmasky, M. E., Actis, L. A., Toranzo, A. E., Barja, J. L. Crosa, J. H. (1985). Plasmids mediating iron uptake in Vibrio anguillarum strains isolated from turbot in Spain. J gen. Microbiol. 131: 1989-1997

Toranzo, A. E., Barja, J. L. Hetrick, F. M. (1982). Survival of Vibrio anguillarum and Pasteurella piscicida in estuarine and fresh waters. Bull. Eur. Ass. Fish Pathol. 3: 43-45

Toranzo, A. E., Barja, J. L., Potter, S. A., Colwell, R. R. Hetrick, F. M., Crosa, J. H. (1983). Molecular factors associated with virulence of marine vibrios isolated from striped bass in Chesapeake Bay. Infection Immunity 39 $1220-1227$

Toranzo, A. E., Baya, A. M., Roberson, B. S., Barja, J. L., Grimes, D. J., Hetrick, F. M. (1987a). Specificity of slide agglutination test for detecting bacterial fish pathogens. Aquaculture 61: 81-97

Toranzo, A. E., Santos, Y., Lemos, M. L., Ledo, A., Bolinches, J. (1987b). Homology of Vibrio anguillarum strains causing epizootics in turbot, salmon and trout reared on the Atlantic Coast of Spain. Aquaculture 67: 41--52

Tubiash, H. S., Chanley, P. E., Leifson, E. (1965). Bacillary necrosis, a disease of larval and juvenile bivalve molluscs. I. Etiology and epizootiology. J. Bacteriol. 90: $1036-1044$

Tubiash. H. S., Colwele, R. R., Sakazaki, R. (1970). Marine vibrios associated with bacillary necrosis: a disease of larval and juvenile molluscs. J. Bacteriol. 103: 271-272

Wiik, R., Hoff, K. A., Andersen, K., Daae, F. L. (1989). Relationship between plasmids and phenotypes of presumptive strains of Vibrio anguillarum isolated from different fish species. Appl. envir Microbiol. 55: 826-831

Yamanoi, H., Muroga, K., Takahashi, S. (1980). Physiological characteristics and pathogenicity of NAG Vibrio isolated from diseased ayu. Fish Pathol. 15: 69-73

Manuscript first received: July 31, 1989 Revised version accepted: May 31, 1990 